\title{
Relationship between visuospatial episodic memory, processing speed and executive function: are they stable over a lifespan?
}

\author{
As relações entre memória episódica visual-espacial, velocidade de processamento e \\ funções executivas são estáveis ao longo do ciclo vital?
}

Bruna Fulgêncio Dias', Letícia Oliveira Rezende', Leandro Fernandes Malloy-Diniz², Jonas Jardim de Paula ${ }^{1,2}$

\begin{abstract}
The present study evaluated the association between episodic memory, executive function and processing speed in a sample with different age ranges. We tested the hypothesis that processing speed, executive function and memory are more strongly associated during childhood and old age. We evaluated 571 participants, aged six to 92 years, divided into four age groups: children/adolescents, young adults, middle-aged adults and older adults. Correlation analyses suggested that the shared variance between the processing speed and memory is strong in childhood but weak across other age ranges. Executive function, however, had a stronger association both in childhood and in old age, when compared with the intermediate stages. We conclude that the effects of processing speed and executive function on memory are not stable across human development. These functions may be compensatory mechanisms for memory functioning in childhood and old age.
\end{abstract}

Keywords: executive function; memory; aging.

\section{RESUMO}

O presente estudo avalia a associação entre velocidade de processamento, funções executivas e memória em uma amostra de diferentes faixas etárias. 0 estudo testa a hipótese de que a velocidade de processamento, as funções executivas e a memória apresentam associação mais forte na infância e na velhice. Avaliamos 571 participantes, com idade entre seis e 92 anos, divididos em quatro grupos etários: crianças/adolescentes, adultos jovens, adultos de meia-idade e idosos. Análises de correlação sugerem que a variância compartilhada entre velocidade de processamento e memória é forte na infância e fraca nas demais idades. Já as funções executivas apresentaram associação forte com a memória tanto na infância quanto na velhice, quando comparadas aos estágios intermediários. Concluímos que os efeitos da atenção sobre a memória variam em função da idade do participante. Essas funções podem ser mecanismos compensatórios para a memória ao longo do desenvolvimento.

Palavras-chave: função executiva; memória; envelhecimento.

Memory is a complex cognitive system with numerous subdivisions. It is usually divided into short-term memory and long-term memory. Long-term memory is responsible for storing information for later use, and is subdivided into declarative (conscious and easily accessible by language) and non-declarative (unconscious and procedural). In the declarative memory, there is another subdivision into episodic and semantic memory. Episodic memory, the focus of this work, is the ability to search for content in declarative long-term memory that depends on a specific event (episode) ${ }^{1}$.

Episodic memory depends on a set of mental processes involving encoding, storage and retrieval of internal or external information ${ }^{1}$. In neurobiological terms, the storage of information in the brain depends on modifications in the structure and connectivity of nerve cells ${ }^{2}$. Memory formation depends on brain plasticity, that is, the ability of brain cells to change their structure and function in a manner consistent with learning processes, and it is largely related to the functioning of the hippocampus and its connections with other brain areas ${ }^{3}$. Depending on its content, episodic memory might also be divided in visuospatial (including information on position, stimulus and visual contents) or verbal (dependent on language skills). These processes are affected by aging, and visuospatial episodic memory shows considerable

${ }^{1}$ Faculdade de Ciências Médicas de Minas Gerais, Belo Horizonte MG, Brasil;

${ }^{2}$ Universidade Federal de Minas Gerais, Belo Horizonte MG, Brasil.

This research was conducted in the Faculdade de Ciências Médicas de Minas Gerais and at the Universidade Federal de Minas Gerais.

Correspondence: Jonas J. de Paula; Faculdade de Medicina da UFMG; Avenida Prof. Alfredo Balena, 190; 30130-10 Belo Horizonte MG, Brasil; E-mail: jonasjardim@gmail.com

Conflict of interest: There is no conflict of interest to declare.

Received 24 July 2017; Received in final form 18 October 2017; Accepted 06 November 2017. 
decline with aging, with better functioning between the second and third decade of life and subsequent reduction into old age ${ }^{4}$. The decline in memory after young adulthood is inherent in human development, but is still significantly affected by a number of factors, including the presence of mental disorders and socio-environmental factors ${ }^{5}$.

Processing speed is a cognitive function related to how quickly and accurately information is processed by other cognitive systems, and it is strongly correlated with the integrity of white matter ${ }^{6}$. Executive function is an umbrella term that represents different cognitive processes related to attentional control, behavioral regulation and goal-directed behavior ${ }^{7}$, and is strongly related to the prefrontal cortex ${ }^{8}$. These two functions, processing speed and executive function, are related to several cognitive, behavioral and functional outcomes across a lifespan, including episodic memory changes ${ }^{9}$.

Longitudinal data suggests that throughout human development, both the evocation of episodic memory content and attention have an inverted " $U$ " development ${ }^{10}$. Children and adolescents show a progressive improvement in episodic memory until early adult life. This means that such processes are inefficient in childhood but optimize throughout maturation, peaking between the second and third decade of life, and declining from that point onwards, following the course of development of cognitive processes of a fluid or effortful nature $^{10}$. Although individual factors (such as intelligence) or environmental factors (such as formal schooling) may affect the development of these functions, in populational terms, the inverted " $U$ " pattern shows good adjustment. Data from studies of typical and clinical samples suggest a relationship between episodic memory, processing speed and executive function. Higher processing speed and better executive function may favor episodic memory, improving codification, storage or retrieval of memory content ${ }^{11,12,13}$. Because episodic memory in childhood and older age is usually less efficient than in middle age, and processing speed and executive function may improve memory functioning, we may assume a stronger association between these at the extremes of development (childhood and old age). In this hypothesis, the processing speed and executive function may be called upon as compensatory mechanisms to avoid memory failures.

The present study aimed to analyze the strength of the association between visuospatial episodic memory, processing speed and cognitive control at different stages of a lifespan. We hypothesized that there is a stronger relationship in children/older adults when compared with middle-age adults and adolescents.

\section{METHODS}

\section{Participants}

We evaluated 571 Brazilians, aged between six and 92 years, in this study. Participants were invited through direct contact by researchers (divided into two teams, one comprising students from the Faculty of Medical Sciences of Minas Gerais and another by students from the Federal University of Minas Gerais), or recruited through advertisements on social networks. The exclusion criteria were the presence of cognitive, sensory or motor impairments that made the evaluation of attention and memory, according to the screening questions in a sociodemographic questionnaire, unfeasible. We also selected participants who were at least six years-old, due to difficulties in evaluating these two mental functions in younger children. The schooling of the sample ranged from incomplete primary education to full/post-graduate higher education.

We divided the participants into four groups: children/adolescents (101 participants aged six to 18 years), young adults (321 participants aged 19 to 34 years), middleaged adults (84 participants aged between 35 and 54 years) and older/elderly adults (65 participants aged 55 years or over). Table 1 presents a brief description of the participants.

\section{Assessment of executive function, processing speed and memory}

The Five Digit Test ${ }^{14}$ : This test is a numerical version of the Stroop color-word paradigm, which evaluates the effect of interference on the attentional system. In this test, the participant must work with numbers and quantities (1 to 5). The Five Digit Test includes four subtests: reading, counting, choosing and switching as shown in the Figure. The first two are simple attention/processing speed measures and the last two are controlled attention/executive function attention. We used the average time of reading and counting subtests as a measure of processing speed and the mean time of inhibition and flexibility scores as a measure of executive function. Higher values in these measures indicates worse performance.

Table 1. Description of participants.

\begin{tabular}{|c|c|c|c|c|c|c|c|c|c|c|}
\hline \multirow[t]{2}{*}{ Group } & \multirow{2}{*}{$\begin{array}{c}\text { Sex (female) } \\
(\%)\end{array}$} & \multirow{2}{*}{$\begin{array}{l}\text { History of mental } \\
\text { disorders (\%) }\end{array}$} & \multicolumn{2}{|c|}{ RCFT recall } & \multicolumn{2}{|c|}{$\begin{array}{c}\text { Formal education } \\
\text { (years) }\end{array}$} & \multicolumn{2}{|c|}{$\begin{array}{l}\text { FDT processing } \\
\text { speed }\end{array}$} & \multicolumn{2}{|c|}{$\begin{array}{l}\text { FDT executive } \\
\text { function }\end{array}$} \\
\hline & & & M & SD & M & SD & M & SD & M & SD \\
\hline $\begin{array}{l}\text { Children and adolescents } \\
(n=101)\end{array}$ & 53 & 1 & 14.90 & 8.80 & 9.30 & 4.14 & 41.92 & 20.73 & 36.54 & 12.68 \\
\hline Young adults $(n=321)$ & 63 & 13 & 22.90 & 6.70 & 14.32 & 2.90 & 19.99 & 10.84 & 23.51 & 6.67 \\
\hline Middle-aged adults $(n=84)$ & 75 & 13 & 18.90 & 6.90 & 15.34 & 4.21 & 24.40 & 10.33 & 26.64 & 7.56 \\
\hline Older adults $(n=65)$ & 77 & 9 & 14.90 & 7.70 & 13.43 & 4.85 & 33.78 & 20.50 & 32.12 & 13.80 \\
\hline
\end{tabular}

M: mean; SD: standard deviation; RCFT: Rey complex figure test; FDT: five digit test. 
The Rey Complex Figure Test ${ }^{15}$ : This is a test to evaluate visuospatial processing, episodic memory and planning. In this test, participants must copy, and then recall, a complex figure of 18 interconnected geometrical elements. Each element is scored based on localization and precision, according to standardized guidelines ${ }^{15}$. In this study, we adopted only the immediate recall of the figure (three minutes after its copying) as a measure of episodic memory. Scores range from 0 to 36, and higher scores are indicative of better performance.

\section{Statistical analysis}

To analyze the association between attention and memory, we used Pearson's correlation, after analyzing the distribution of the data (the measurements showed a pattern compatible with normal distribution). We computed the correlations in each of the age groups. To facilitate the interpretation of the data and to avoid biases in the direction of correlations, we also calculated the shared variance $\left(\mathrm{r}^{2}\right)$ between the measures of the study.

\section{Ethical aspects}

The study was approved by the Research Ethics Committee of the Medical Sciences Faculty of Minas Gerais (CAAE: 45381515.4.0000.5134). All the participants in the research were given a Free and Informed Consent Form, which was signed by them or the person responsible for them, as in the case of children and adolescents. The researchers made themselves available to the participants to clarify any doubts presented.

\section{RESULTS}

The performances of the four age groups in the measurements of processing speed, executive function and episodic memory are shown in Table 1 . The mean values for each neuropsychological test suggests that the measures showed the hypothesized pattern of an inverted " $U$ ".

Table 2 shows the correlations and shared variance between the cognitive measures adopted in the studies. The association of processing speed and memory was strong during childhood/adolescence, but weak in the other age groups,

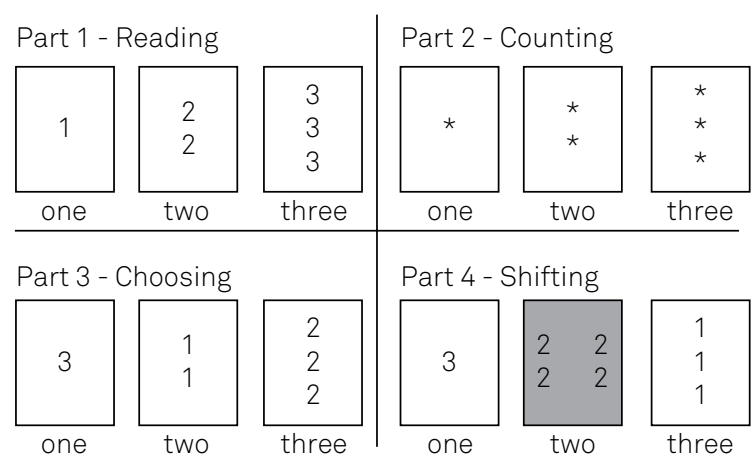

Figure. Five digit test (adapted from Paiva et al., 2016) 14. $^{14}$ suggesting a stronger relationship between these constructs only in the early stages of development. Executive function showed a stronger correlation with episodic memory in childhood and old age, and a weaker correlation in young adulthood and middle age.

\section{DISCUSSION}

Our results suggested that the association between the processing speed, executive function and visual episodic memory depended on the participants' ages. In children, we observed a strong association between the processing speed, executive function and memory in both automatic and controlled attention processes. In young and middle-aged adults, the associations were weak for both processes. In the elderly, there was a weak association between the processing speed and memory but a strong association between executive function and memory. Based on our initial hypothesis, only executive function was strongly associated with memory at the age extremes.

Although the cognitive changes associated with human development have been extensively mapped over the last century $^{10}$, and their course is well known, there are still some open questions about how different cognitive functions are associated in different phases of life. The hypothesis tested in the present study was based on the compensatory recruitment models, as discussed by Han and colleagues ${ }^{16}$. This model proposes that, in developmental stages where a mental function is not at its optimal level, other mental functions are recruited to maintain good functioning in the individual. The phenomenon would be similar to that observed in acquired brain lesions where, after compromising a mental function associated with a certain region, the organism tries to reorganize itself, in terms of plasticity, to compensate for the deficits ${ }^{17}$.

The theory presupposes that throughout the development there is a functional specialization of different cerebral regions for the accomplishment of specific cognitive functions. This specialization would reach its apex in young adulthood, where cognitive function would show greater specificity in brain regions. Functional specialization, however, is smaller during childhood when the still-maturing brain has not fully developed cognitive abilities, and in old age, when the cognitive decline in aging leads to the recruitment of

Table 2. Correlations and shared variance between episodic memory, processing speed and executive function in different age ranges.

\begin{tabular}{|c|c|c|c|c|}
\hline \multirow[t]{2}{*}{ Variable } & \multicolumn{2}{|c|}{$\begin{array}{l}\text { Processing } \\
\text { Speed }\end{array}$} & \multicolumn{2}{|c|}{$\begin{array}{l}\text { Executive } \\
\text { Function }\end{array}$} \\
\hline & $r$ & $r^{2}$ & $r$ & $r^{2}$ \\
\hline Children and adolescents & $-0.545^{\star \star}$ & $30 \%$ & $-0.435^{\star \star}$ & $19 \%$ \\
\hline Young adults & $-0.180 * *$ & $3 \%$ & $-0.235 * \star$ & $6 \%$ \\
\hline Middle-age adults & $-0.222 * \star$ & $5 \%$ & $-0.225^{\star \star}$ & $5 \%$ \\
\hline Older adults & $-0.284 * \star$ & $8 \%$ & $-0.558 * \star$ & $31 \%$ \\
\hline
\end{tabular}


several mental functions for the maintenance of performance ${ }^{18}$. This can be observed, for example, in functional neuroimaging studies ${ }^{19}$. Our data endorse this perspective, suggesting a greater association of executive function and memory in age extremes, where shared variance between the measure of executive function and memory was higher (19\% in children/adolescent and $31 \%$ in older adults) when compared to young or mid-adult life ( $6 \%$ and $5 \%$ ).

Executive functions are a set of top-down mental processes that allow goal-directed behavior ${ }^{7}$. They involve conscious processes, are energy intensive and motivational, and strongly related to the prefrontal regions of the brain. Executive functions connect to the attentional and memory systems, allowing the possibility of effortful control of these processes. In this sense, these controlled and effortful processes would be used by children and older adults in learning processes, supporting episodic memory. Processing speed would have a closer relationship with memory only in childhood, perhaps because it represents a more global aspect of mental functioning, which is still in specialization ${ }^{20}$.
The study has limitations that should be considered. First, although we have a reasonable sample size in the study, the age group division was not equal, with most participants being young adults. The convenience sample does not represent the variability of the Brazilian population, and reduces the generalization potential of our results. We also adopted the Rey Complex Figure Test as a measure of episodic memory; however, test performance depends on other factors including IQ, motor coordination and other aspects of visuospatial abilities ${ }^{21}$. Nevertheless, the study presents positive points, such as the well-established hypothesis, the use of representative and validated measures of attention and memory, and good use of cross-sectional data.

In conclusion, our results suggest that the association between attentional processes and memory varies according to age. In children and older adults, there is a greater association between executive function and memory. The association of processing speed with memory was strong only during childhood and adolescence. We believe this reflects the compensatory mechanisms that recruit additional functions to maintain good functioning in daily life.

\section{References}

1. Squire LR. Memory systems of the brain: a brief history and current perspective. Neurobiol Learn Mem. 2004 Nov;82(3):171-7. https://doi.org/10.1016/j.nlm.2004.06.005

2. Squire LR, Genzel L, Wixted JT, Morris RG. Memory consolidation. Cold Spring Harb Perspect Biol. 20153;7(8):a021766.

3. Henke K. A model for memory systems based on processing modes rather than consciousness. Nat Rev Neurosci. 2010 Jul;11(7):523-32. https://doi.org/10.1038/nrn2850

4. Tromp D, Dufour A, Lithfous S, Pebayle T, Després O. Episodic memory in normal aging and Alzheimer disease: Insights from imaging and behavioral studies. Ageing Res Rev. 2015;24(Pt B):232-62.

5. Cheng ST. Cognitive Reserve and the Prevention of Dementia: the Role of Physical and Cognitive Activities. Curr Psychiatry Rep. 2016 Sep;18(9):85. https://doi.org/10.1007/s11920-016-0721-2

6. Kuznetsova KA, Maniega SM, Ritchie SJ, Cox SR, Storkey AJ, Starr JM et al. Brain white matter structure and information processing speed in healthy older age. Brain Struct Funct. $2016 \mathrm{Jul}$;221(6):3223-35. https://doi.org/10.1007/s00429-015-1097-5

7. Diamond A. Executive functions. Annu Rev Psychol. 2013;64(1):135-68. https://doi.org/10.1146/annurev-psych-113011-143750

8. Nowrangi MA, Lyketsos C, Rao V, Munro CA. Systematic review of neuroimaging correlates of executive functioning: converging evidence from different clinical populations. J Neuropsychiatry Clin Neurosci. 2014 Apr;26(2):114-25. https://doi.org/10.1176/appi.neuropsych.12070176

9. Lee T, Crawford JD, Henry JD, Trollor JN, Kochan NA, Wright MJ et al. Mediating effects of processing speed and executive functions in age-related differences in episodic memory performance: a cross-validation study. Neuropsychology. 2012 Nov;26(6):776-84. https://doi.org/10.1037/a0030053

10. Shing YL, Werkle-Bergner M, Brehmer Y, Müller V, Li SC, Lindenberger $U$. Episodic memory across the lifespan: the contributions of associative and strategic components. Neurosci Biobehav Rev. 2010 Jun;34(7):1080-91. https://doi.org/10.1016/j.neubiorev.2009.11.002

11. Baudouin A, Clarys D, Vanneste $S$, Isingrini M. Executive functioning and processing speed in age-related differences in memory: contribution of a coding task. Brain Cogn. 2009 Dec;71(3):240-5. https://doi.org/10.1016/j.bandc.2009.08.007

12. Fellows RP, Byrd DA, Morgello S. Effects of information processing speed on learning, memory, and executive functioning in people living with HIV/AIDS. J Clin Exp Neuropsychol. 2014;36(8):806-17. https://doi.org/10.1080/13803395.2014.943696

13. Noël X, Van der Linden M, Brevers D, Campanella S, Hanak C, Kornreich $\mathrm{C}$ et al. The contribution of executive functions deficits to impaired episodic memory in individuals with alcoholism. Psychiatry Res. 2012 Jun;198(1):116-22. https://doi.org/10.1016/j.psychres.2011.10.007

14. Paiva GC, Fialho MB, Costa DS, Paula JJ. Ecological validity of the five digit test and the oral trails test. Arq Neuropsiquiatr. 2016 Jan;74(1):29-34. https://doi.org/10.1590/0004-282X20150184

15. Shin MS, Park SY, Park SR, Seol SH, Kwon JS. Clinical and empirical applications of the Rey-Osterrieth Complex Figure Test. Nat Protoc. 2006;1(2):892-9. https://doi.org/10.1038/nprot.2006.115

16. Han SD, Bangen KJ, Bondi MW. Functional magnetic resonance imaging of compensatory neural recruitment in aging and risk for Alzheimer's disease: review and recommendations. Dement Geriatr Cogn Disord. 2009;27(1):1-10. https://doi.org/10.1159/000182420

17. Chen H, Epstein J, Stern E. Neural plasticity after acquired brain injury: evidence from functional neuroimaging. PM R. 2010 Dec;2(12 Suppl 2):S306-12 https://doi.org/10.1016/j.pmrj.2010.10.006

18. Reuter-Lorenz PA, Cappell KA. Neurocognitive aging and the compensation hypothesis. Curr Dir Psychol Sci. 2008;17(3):177-82. https://doi.org/10.1111/j.1467-8721.2008.00570.x

19. Cabeza R, Anderson ND, Locantore JK, McIntosh AR. Aging gracefully: compensatory brain activity in high-performing older adults. Neuroimage. 2002 Nov;17(3):1394-402. https://doi.org/10.1006/nimg.2002.1280

20. Salthouse TA, Meinz EJ. Aging, inhibition, working memory, and speed. J Gerontol B Psychol Sci Soc Sci. 1995 Nov;50(6):297-306. https://doi.org/10.1093/geronb/50B.6.P297

21. Strauss E, Sherman EM, Spreen O. A compendium of neuropsychological tests: Administration, norms, and commentary. Oxford: Oxford University Press; 2006. 